\title{
DAMPAK COVID-19 TERHADAP AKTIVITAS SOSIAL MASYARAKAT DI KOTA LUBUKLINGGAU
}

\section{Ramelia Dwi Anisa, Rusdinal dan Firman}

Univerisitas Negeri Padang Sumatera Barat, Indonesia

Email:rameliadwianisa@gmail.com,rusdinal@fip.unp.ac.id dan firman@konselor.org

\section{Abstract}

Coronavirus Diseases (Covid-19) is one of the many viruses that can attack humans, ranging from those without symptoms, with mild symptoms to severe symptoms. What is known is that the incubation period for Covid-19 in the human body ranges from 5-6 days and the longest incubation period is 14 days. In the current Covid-19 era, there are a lot of social activities in society that are not disturbed and cannot even be done to anticipate the spread of Covid-19 in their neighborhood. There are also community activities that have undergone changes and concerts must be carried out as a result of Covid-19. The purpose of this study was to identify the impact of Covid-19 on the social activities of the people of Lubuklinggau City. This research uses descriptive field research with qualitative research methods. The data techniques used in this study were observation, documentation and interviews and used descriptive analysis methods as data analysis techniques. The results obtained from the impact are anything that arises as a result of changes that occur in people's lives and can produce a change with a positive impact and a negative impact on the survival of the community. The results obtained in conducting research related to the impact of Covid-19 on community activities, the authors found that there are impacts that arise as a result of the existence of Covid-19, both positive and negative impacts that appear in the midst of society today.

Keywords: impact; social activit; public

\begin{abstract}
Abstrak
Coronavirus Diseases (Covid-19) adalah salah satu dari sekian banyak virus yang dapat menyerang manusia mulai dari yang tidak mempunyai gejala, bergejala ringan hingga bergejala berat. Sebagaimana yang di ketahui bahwasannya masa inkubasi Covid-19 dalam tubuh manusia yaitu berkisar 5-6 hari dan masa inkubasi terpanjang adalah 14 hari. Pada masa Covid-19 sekarang ini, banyak sekali aktivitas sosial di dalam masyarakat yang terganggu dan bahkan tidak dapat di lakukan karena untuk mengantisipasi penyebaran Covid-19 di dalam lingkungan mereka tinggal. Ada juga aktivitas masyarakat yang mengalami perubahan dan harus dilakukan penyesuaian di akibatkan dari Covid-19 ini. Tujuan dilakukannya penelitian ini adalah untuk mengidentifikasi dampak Covid-19 terhadap aktivitas sosial masyarakat Kota Lubuklinggau. Penelitian ini menggunakan penelitian lapangan yang bersifat deskriptif dengan metode penelitian kualitatif. Teknik pengumpulan data yang digunakan dalam penelitian ini yaitu observasi, dokumentasi dan wawancara serta dengan menggunakan metode analisis deskriptif
\end{abstract}


sebagai teknik analisis data. Hasil yang di dapat yaitu dampak adalah segala sesuatu yang muncul sebagai akibat dari adanya perubahan yang terjadi di dalam kehidupan masyarakat dan dapat menghasilkan suatu perubahan dengan dampak yang bersifat positif maupun dampak yang bersifat negatif terhadap keberlangsungan hidup masyarakat.

Kata kunci: dampak; aktivitas sosial; masyarakat

\section{Coresponden Author}

Email: rameliadwianisa@gmail.com Artikel dengan akses terbuka dibawah lisensi

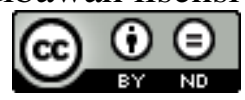

\section{Pendahuluan}

Sekarang ini, dunia sedang di gemparkan oleh sebuah virus menular yang berasal dari Wuhan, China. Virus tersebut di beri nama Corona Virus Diseases 2019 atau yang lebih dikenal dengan sebutan Covid-19. Covid-19 menyerang sistem pernapasan manusia, sehingga tak jarang orang yang terkonfirmasi Covid-19 akan mengalami sesak napas (Syakurah, R. A., \& Moudy, 2020). Selain itu gejala lain yang dimuncul jika orang terkonfirmasi positif Covid-19 ini adalah demam tinggi, batuk dan pilek serta hilangnya indera penciuman. Covid-19 ini sekarang telah menyebar hampir ke seluruh penjuru dunia termasuk Indonesia salah satunya (Nurhalimah, 2020).

Indonesia Covid-19 pertama kali masuk pada 02 Maret 2020, dimana pada tanggal tersebut Indonesia melaporkan kasus pertamanya (Pasaribu, 2020). Sejak saat itu hingga sekarang Indonesia tercatat telah ada 965,283 orang yang terkonfirmasi positif Covid19, 27,453 orang meninggal dan 781,147 dinyatakan telah sembuh dari Covid-19 (sumber : Website Kemkes.go.id).

Coronavirus Diseases (Covid-19) adalah salah satu dari sekian banyak virus yang dapat menyerang manusia mulai dari yang tidak mempunyai gejala, bergejala ringan hingga bergejala berat (Tandra, 2021). Sebagaimana yang di ketahui bahwasannya masa inkubasi Covid-19 dalam tubuh manusia yaitu berkisar 5-6 hari dan masa inkubasi terpanjang adalah 14 hari (Putra, 2020).

Adanya kasus konfirmasi positif di Indonesia, pemerintah Indonesia mulai mengintruksikan kepada pemerintah daerah untuk mengeluarkan kebijakan-kebijakan yang bertujuan untuk mencegah penyebaran Covid-19 di dalam lingkungan masyarakat salah satunya yaitu pemerintah Kota Lubuklinggau.

Sejak masuknya Covid-19 di Indonesia dan merebak ke daerah-daerah yang ada di Indonesia, Pemerintah Kota Lubuklinggau mengeluarkan Surat Edaran Nomor 518/BKPSDM/2020 Tentang Resiko Pencegahan Resiko Penularan Infeksi Corona Virus Diseases (Covid-19) yang berisi tentang himbauan untuk melaksanakan kegiatan dari rumah mulai dari bekerja dari rumah, belajar dari rumah untuk PAUD/TK/SD/SMP/SMA, meniadakan Car Free Day (CFD), melakukan pemeriksaan disetiap pintu masuk dan keluar dari Kota Lubuklinggau pada setiap perbatasan daerah 
dan larangan mengumpulkan orang banyak termasuk di dalamnya acara pengajian, arisan, pesta pernikahan dan berkerumun di tempat umum tanpa menjaga jarak. Dengan keluarnya Surat Edaran Pemerintah tersebut tentunya menimbulkan dampak yang terjadi di dalam aktivitas masyarakat.

Selain Surat Edaran tersebut, Pemerintah Kota Lubuklinggau juga mengeluarkan Peraturan Pemerintah Nomor 31 Tahun 2020 tentang Penerapan Disiplin dan Penegakkan Hukum Protokol Kesehatan Covid-19, yang isi dari peraturan tersebut menjelaskan tentang kewajiban mematuhi protokol kesehatan seperti memakai masker, menjaga jarak, mencuci tangan pakai sabun atau hand sanitizer serta tempat usaha juga wajib mematuhi protokol kesehatan dan menyediakan tempat cuci tangan di pintu masuk. Selanjutnya, akan diberikan sanksi dan hukum bagi yang melanggar peraturan tersebut.

Aktivitas sosial merupakan suatu kegiatan yang dilakukan oleh suatu masyarakat secara bersama di lingkungan sekitar (Subiyakto, B., \& Mutiani, 2019). Aktivitas sosial adalah suatu kegiatan yang dalam kehidupan sehari-hari dilakukan oleh masyarakat baik kelompok maupun individu di lingkungan tempat tinggal mereka (Tabi'in, 2017). Banyak bentuk dari aktivitas yang dapat dilakukan oleh masyarakat dalam kehidupan sehari-hari mereka seperti pergi ke pasar, bertegur sapa dan berkumpul bersama tetangga, mengikuti kegiatan pengajian, arisan serta bekerja baik bekerja di kantor maupun di lapangan semua hal tersebut termasuk ke dalam aktivitas yang sering di lakukan oleh masyarakat dalam kehidupan sehari-hari mereka.

Pada masa Covid-19 sekarang ini, banyak sekali aktivitas sosial didalam masyarakat yang terganggu dan bahkan tidak dapat di lakukan karena untuk mengantisipasi penyebaran Covid-19 di dalam lingkungan mereka tinggal (Mardiyah ${ }^{1}$, R. A., \& Nurwati, 2020). Ada juga aktivitas masyarakat yang mengalami perubahan dan harus dilakukan penyesuaian di akibatkan dari Covid-19 ini.

Kota Lubuklinggau banyak aktivitas atau kegiatan sosial seperti pengajian dan arisan yang terhenti karena adanya kebijakan untuk tidak membuat kerumunan ditempat umum dan tempat ibadah, baik itu tempat yang terbuka maupun tempat tertutup. Pengajian dan arisan harus terhenti sementara selama beberapa bulan hingga keluar Surat Edaran baru oleh pemerintah. Tidak hanya pengajian dan arisan saja masyarakat sesama lingkungan tempat tinggal saja saat ini sudah jarang berkumpul dan bertegur sapa dikarenakan takut dengan Covid-19. Walaupun tidak menutup kemungkinan terkadang masih ada masyarakat yang berkumpul sesama tetangga di lingkungan tempat tinggal mereka dan itu pun harus menggunakan masker dan menjaga jarak. Selain itu, banyak juga pesta pernikahan yang tertunda atau mundur akibat dari kebijakan yang pemerintah keluarkan tersebut.

Aktivitas sosial yang ada di lingkungan pasar juga mengalami dampak dari Covid-19 ini. Pasar yang biasanya ramai dan penuh sesak oleh pembeli pun menjadi sepi karena banyaknya masyarakat yang takut akan tertular Covid-19. Aktivitasaktivitas yang biasanya dilakukan diluar rumah sekarang beralih dan diharuskan 
dilakukan dari rumah. Bahkan sampai sekarang siswa sekolah masih melakukan pembelajaran dari rumah secara online.

Dalam penelitian ini digunakan dua penelitian terdahulu yang digunakan sebagai rujukan ilmiah, yaitu: Penelitian terdahulu yang pertama dilakukan oleh Silpa Hanoatubun yang berjudul "Dampak Covid-19 Terhadap Perekonomian Indonesia". dimana penelitian ini dilakukan bertujuan untuk mengetahui dampak dari Covid-19 terhadap perekonomian di Indonesia saat ini. Hasil penelitian menunjukkan bahwa Covid-19 berdampak pada perekonomian Indonesia saat ini.Karena berbagai dampak ekonomi yang ditimbulkan oleh pandemi Covid-19 saat ini, perlu diketahui apa yang terjadi yaitu sulitnya mencari pekerjaan dan sulitnya memuaskan kehidupan sehari-hari. Kebutuhan dan tidak adanya penghasilan untuk memenuhi kebutuhan hidup sehari-hari, dan diberbagai bidang, berbagai sektor perekonomian juga banyak mengalami kesulitan dan dampak yang dirasakan akibat Covid-19 (Hanoatubun, 2020).

Selanjutnya penelitian terdahulu yang kedua dilakukan oleh Wahyu Aji, Fatma Dewi yang berjudul "Dampak Covid-19 Terhadap Implementasi Pembelajaran Daring di Sekolah Dasar". Di mana penelitian ini dilakukan bertujuan untuk mengidentifikasi implementasi pembelajaran daring di rumah pada siswa sekolah dasar sebagai akibat dari adanya pandemi Covid-19. Hasil penelitian ini menunjukkan bahwa Covid-19 berdampak pada pelaksanaan pembelajaran di sekolah dasar yang dapat terlaksana dengan baik apabila guru, siswa, dan orang tua bekerja sama dalam pembelajaran di rumah (Dewi, 2020).

Berdasarkan dari penjelasan di atas serta penelitian pendahulu, maka penulis mengambil judul artikel ini yaitu tentang "Dampak Covid-19 Terhadap Aktivitas Sosial Masyarakat di Kota Lubuklinggau".

Tujuan dari penelitian ini adalah untuk menganalisis dampak Covid-19 terhadap aktivitas sosial masyarakat di Kota Lubuklinggau. Manfaat penelitian ini bagi ilmu pengetahuan adalah untuk dapat memberikan sumbangan bagi ilmu pengetahuan sebagai wahana untuk menerapkan teori yang didapat selama perkuliahan serta dapat menghasilkan karya tulis ilmiah yang bermanfaat bagi disiplin ilmu pengetahuan sosial khususnya konsentrasi sosiologi.

\section{Metode Penelitian}

Dalam melakukan penelitian ini penulis menggunakan penelitian lapangan yang bersifat deskriptif sebagai jenis penelitian yang digunakan yaitu dilakukan dengan cara menggambarkan serta mengumpulkan data ataupun informasi mengenai keadaan dan objek yang diteliti dengan sebagaimana adanya kesesuaian sama dan sesuai data yang didapat di lapangan (Anggito, A \& Setiawan, 2018). Kemudian penelitian ini juga menggunakan metode penelitian kualitatif (Gunawan, 2013). Selain jenis penelitian yang dilakukan dengan penelitian lapangan, maka dalam penelitian ini juga menggunakan teknik pengumpulan data observasi dan wawancara (Sukmadinata, 2005), (Arikunto, 2010). Teknik pengumpulan data digunakan agar data penelitian dapat diperoleh serta merupakan langkah yang paling utama dalam melakukan suatu 
penelitian (Nurhasanah, S., \& Sobandi, 2016). Dalam penelitian ini, penulis menggunakan metode analisis deskriptif.

\section{Hasil dan Pembahasan}

Kota Lubuklinggau kasus konfirmasi positif saat ini telah mencapai angka 1.200 kasus, meninggal 40 kasus dan yang sembuh 1.093 kasus (Sumber : Diskominfo Kota Lubuklinggau). Banyaknya kasus konfirmasi yang ada di Kota Lubuklinggau membuat pemerintah lebih memperketat penerapan protokol kesehatan dan larangan terhadap kegiatan-kegiatan yang dapat membuat kerumunan di tengah masyarakat.

Pada saat melakukan penelitian terkait dengan dampak Covid-19 terhadap aktivitas masyarakat, penulis menemukan bahwa ada dampak yang muncul akibat dari adanya Covid-19, baik dampak yang membawa pengaruh baik atau positif maupun dampak yang membawa pengaruh buruk atau negatif yang muncul di tengah-tengah masyarakat.

Penulis melakukan observasi di Kota Lubuklinggau untuk melihat dampak Covid19 terhadap masyarakat dan disini penulis melihat banyak Covid-19 membawa dampak yang sangat kuat terhadap kehidupan dan aktivitas sosial masyarakat di Kota Lubuklinggau. Masyarakat yang biasanya sering berkumpul dan mengadakan banyak kegiatan, namun sekarang untuk mengadakan kegiatan yang sifatnya menimbulkan keramaian dilarang diadakan oleh pemerintah dan pihak kepolisian dan dampak Covid19 ini lebih jelas terlihat pada saat masyarakat melakukan aktivitas diluar rumah seperti berpergian kepasar atau tempat yang ramai orang mereka harus menggunakan masker dan menjaga jarak agar tidak tertular Covid-19.

Covid-19 telah memberikan dampak yang sangat mempengaruhi kegiatan dan aktivitas masyarakat. Kita dapat melihat setidaknya dua dampak Covid-19 terhadap aktivitas masyarakat yaitu dampak Covid-19 terhadap aktivitas sosial masyarakat dan dampak Covid-19 terhadap aktivitas ekonomi masyarakat. Aktivitas ekonomi sangat merasakan dampak dari adanya Covid-19 ini. Namun, pada penelitian kali ini penulis hanya akan membahas tentang dampak Covid-19 terhadap aktivitas sosial masyarakat yang ada di Kota Lubuklinggau.

Penulis melakukan kesempatan melakukan wawancara dengan beberapa masyarakat terkait dengan dampak Covid-19 terhadap masyarakat. Pertama penulis melakukan wawancara kepada Ibu RM yang mengatakan bahwa "selama Covid-19 mereka jarang keluar rumah, keluar rumah hanya untuk ke warung atau ada kebutuhan mendesak saja itu pun kalau keluar rumah harus pakai masker bawa hand sanitizer untuk antisipasi agar tidak terkena Covid-19”.

Selanjutnya penulis juga melakukan wawancara dengan Ibu YN yang mengatakan bahwa "sekarang kalau mau melakukan sesuatu yang ada orang banyak itu takut, harus bener-bener mengikuti protokol kesehatan. Kumpul-kumpul sama tetangga saja takut dan banyak kegiatan yang di tunda karena Covid-19."

Wawancara lain juga penulis lakukan dengan Bapak HS, yang mengatakan bahwa "selama Covid-19 ini ia hanya dirumah saja sesuai dengan anjuran dan himbauan dari 
pemerintah dan kebetulan ia juga melakukan pekerjaan dari rumah, ia juga mengatakan bahwa Covid-19 ini ada hikmahnya karena bisa berkumpul dan menghabiskan waktu lebih lama bersama keluarga dirumah. Namun banyak acara atau kegiatan yang telah direncanakan ditunda. Bisa dilihat dari peringatan HUT RI kemarin tidak ada acara peringatan seperti lomba-lomba padahal biasanya banyak acara, banyak kegiatan dan ramai bukan itu saja untuk berkumpul sekedar berbincang dengan tetangga saja sekarang kita khawatir dan takut-takut."

Berdasarkan hasil wawancara yang dilakukan di atas dapat kita simpulkan bahwa adanya Covid-19 ini membawa dampak yang sangat kuat dirasakan oleh masyarakat. Banyak kegiatan dan acara yang telah mereka rencanakan menjadi tertunda, kurangnya interaksi antar sesama tetangga karena takut tertular dan menularkan Covid-19. Selain itu, Covid-19 juga dapat membuat kita menjadi lebih dekat dengan keluarga.

Perubahan yang terjadi di tengah-tengah masyarakat pada saat Covid-19 ini membawa dampak dan pengaruh tersendiri bagi masyarakat di Kota Lubuklinggau. Karena dampak terjadi karena adanya perubahan yang terjadi I di tengah masyarakat. Dampak akan sangat terasa saat di lingkungan tinggal suatu masyarakat terdapat satu orang atau satu keluarga di dalam lingkungan tempat tinggal masyarakat ada yang terkonfirmasi positif Covid-19.

Penelitian melakukan observasi untuk melihat dampak apa saja yang disebabkan oleh adanya Covid-19 ini. Saat melakukan observasi penulis melihat ada masyarakat yang melakukan pembagian sembako kepada masyarakat miskin atau yang membutuhkan yang terdampak Covid-19. di mana dalam proses pembagian sembako didampingi oleh BABINKAMTIBNAS dari kepolisian dan BABINSA dari Kodim 0406 Lubuklinggau, pembagian sembako ini dilakukan dengan mengikuti protokol kesehatan yang sangat ketat, semua diwajibkan menggunakan masker, menjaga jarak dan mencuci tangan sebelum masuk ke dalam area tempat pembagian sembako.

Dari observasi yang dilakukan maka dapat kita lihat dampak yang ada dari adanya Covid-19 yaitu untuk membuat suatu kegiatan harus membuat surat izin keramaian dan mematuhi protokol kesehatan tidak boleh lagi berkumpul tanpa menggunakan masker biasanya kalau tidak ada Covid untuk melakukan kegiatan pembagian sembako tidak perlu pake masker, menjaga jarak dan mencuci tangan apalagi sampai dengan di awasi oleh BABINKAMTIBNAS dan BABINSA, masyarakat dapat dengan bebas berkumpul berbincang ditengah keramaian. Namun sekarang, tidak dapat lagi untuk melakukan hal seperti itu, kegiatan masyarakat sangat terbatas dan interaksi dan komunikasi yang terjadi juga hanya dapat dilakukan seadanya.

Dari berbagai penjelasan dan wawancara yang telah dilakukan dan dijelaskan di atas, maka dapat kita simpulkan bahwa dampak yang di timbulkan sebagai akibat dari adanya Covid-19 terhadap aktivitas sosial masyarakat adalah adanya dampak yang bersifat positif dan dampak negatif. Dampak positif adalah dampak yang memberikan pengaruh baik terhadap masyarakat dan dampak negatif adalah dampak yang memberikan pengaruh yang tidak baik atau dampak yang merugikan dan dapat mempersulit masyarakat. 
Jika lihat dari penjelasan dan wawancara yang dilakukan maka dapat kita ketahui bahwa dampak positif dari Covid-19 terhadap aktivitas sosial masyarakat adalah sebagai berikut :

1. Membuat masyarakat untuk menjadi lebih dekat dengan Allah

2. Membuat masyarakat untuk lebih mensyukuri nikmat yang diberikan oleh Allah, salah satunya yaitu mensyukuri nikmat sehat.

3. Membuat masyarakat untuk lebih bersabar dalam segala keadaan.

4. Membuat masyarakat lebih dekat dengan keluarga dengan berkumpul dan menghabiskan waktu bersama dirumah selama Covid-19.

5. Membuat masyarakat untuk saling membantu dalam kesulitan selama masa Covid-19 ini.

6. Membuat masyarakat terbiasa untuk menerapkan pola hidup bersih dan sehat

Selanjutnya, dapat kita lihat juga dampak negatif yang muncul akibat adanya Covid-19 terhadap aktivitas masyarakat adalah sebagai berikut :

1. Banyaknya kegiatan yang tertunda dan bahkan dibatalkan

2. Kurangnya komunikasi yang terjadi di antara masyarakat

3. Ruang gerak masyarakat menjadi terbatas karena adanya kebijakan-kebijakan terkait Covid-19 yang harus dipatuhi.

4. Membuat hubungan masyarakat menjadi renggang. Hal ini disebabkan karena kurangnya komunikasi langsung yang terjadi di tengah masyarakat baik antar sesama tetangga maupun antar sesama keluarga sendiri.

5. Orang yang sakit dikucilkan. Hal ini dikarenakan ketakutan masyarakat terhadap Covid-19, padahal orang yang sakit belum tentu Covid-19.

6. Membuat aktivitas di pasar menjadi sepi yang menyebabkan menurunnya pendapatan pedagang pasar.

7. Menyebabkan ditutupnya tempat ibadah dan fasilitas umum lainnya yang membuat banyaknya kegiatan masyarakat yang di tunda.

8. Menyebabkan banyak terjadinya tindak kekerasan dalam keluarga yang terjadi di lingkungan masyarakat seperti maling, rampok dan jambret hal ini disebabkan karena penghasilan yang menurun dan sedikit selama Covid-19.

Dari penelitian yang dilakukan hanya itu yang baru penulis temukan tentang dampak Covid-19 terhadap aktivitas masyarakat, sebenarnya mungkin banyak lagi dampak-dampak lain yang muncul akibat dari adanya Covid-19 ini. Namun, mungkin hanya yang dijelaskan dan disampaikan yang dirasakan oleh masyarakat terkait dampak Covid-19 terhadap aktivitas masyarakat yang telah penulis teliti dan observasi. Jika dilihat dari hasil penelitian ini bahwa dampak yang muncul akibat dari adanya Covid-19 ini adalah lebih banyak dampak negatifnya dari pada dampak positifnya. Masyarakat diharapkan untuk lebih berhati-hati dalam menghadapi dampak negatif yang muncul akibat adanya Covid-19 dan juga masyarakat harus membuat kegiatan-kegiatan yang bersifat positif agar dampak positif dapat muncul dari kegiatan tersebut dengan tetap menerapkan dan mematuhi protokol kesehatan Covid-19. 


\section{Kesimpulan}

Dampak Covid-19 terhadap aktivitas sosial masyarakat itu ada dampak positifnya dan dampak negatifnya. Dampak positif Covid-19 terhadap aktivitas sosial masyarakat adalah menjadikan masyarakat lebih dekat kepada penciptanya yaitu Allah SWT, menjadikan masyarakat untuk lebih banyak bersyukur, memperbanyak bersabar, membuat masyarakat menjadi lebih banyak waktu untuk berkumpul dan menghabis waktu bersama keluarga, membuat masyarakat untuk dapat saling membantu dalam segala keadaan, menjadikan masyarakat untuk terbiasa menerapkan pola hidup bersih dan sehat. Dampak negatifnya yaitu banyak acara dan kegiatan yang telah di rencanakan dari jauh hari menjadi tertunda dan bahkan dibatalkan, komunikasi antar masyarakat menjadi berkurang, membuat hubungan masyarakat menjadi renggang, orang yang sakit dikucilkan karena takut Covid-19, aktivitas dipasar menjadi sepi, ditutupnya tempat ibadah dan beberapa fasilitas umum lainnya, banyaknya terjadi tindak kekerasan selama Covid-19. 


\section{BIBLIOGRAFI}

Anggito, A \& Setiawan, j. (2018). Metodologi Penelitian Kualitatif. CV Jejak Publisher.

Arikunto, S. (2010). Metode Penelitian. Rineka Cipta.

Dewi, W. A. F. (2020). Dampak Covid-19 terhadap implementasi pembelajaran daring di sekolah dasar. Jurnal Ilmu Pendidikan.

Gunawan, I. (2013). Metode Penelitian Kualitatif. Bumi Aksara.

Hanoatubun, S. (2020). Dampak Covid-19 terhadap Prekonomian Indonesia. Jurnal Of Education, Psychology and Counseling.

Mardiyah $^{1}$, R. A., \& Nurwati, R. N. (2020). Dampak pandemi Covid-19 terhadap peningkatan angka pengangguran di Indonesia.

Nurhalimah, N. (2020). Upaya Bela Negara melalui sosial distancing dan lockdown untuk mengatasi wabah Covid-19 (Efforts to Defend the Country Through Social Distancing and Lockdown to Overcome the COVID-19 Plague).

Nurhasanah, S., \& Sobandi, A. (2016). Minat belajar sebagai determinan hasil belajar siswa. Jurnal Pendidikan Manajemen Perkantoran (JPManper).

Pasaribu, J. . (2020). Masalah Penyakit Menular dan Virus Corona.

Putra, I. M. (2020). Analisis Determinan Kepatuhan Masyarakat Terhadap Pelaksanaan Protokol Kesehatan CoronaVirus Disease 2019 (COVID-19) Di Kecamatan Percut Sei Tuan Kabupaten Deli Serdang.

Subiyakto, B., \& Mutiani, M. (2019). ). Internalisasi nilai pendidikan melalui aktivitas masyarakat sebagai sumber belajar ilmu pengetahuan sosial. Jurnal Studi Islam Dan Humaniora.

Sukmadinata, S. (2005). Metode Penelitian. PT. Remaja Rosdakarya: Bandung

Syakurah, R. A., \& Moudy, J. (2020). Pengetahuan terkait usaha pencegahan Coronavirus Disease (COVID-19) di Indonesia. Journal of Public Health Research and Development.

Tabi'in, A. (2017). Menumbuhkan sikap peduli pada anak melalui interaksi kegiatan sosial. Journal of Social Science Teaching.

Tandra, H. (2021). Virus Corona Baru Covid-19: Kenali, Cegah, Lindungi Diri Sendiri \& Orang Lain. Rapha Publishing. 